\title{
Adana 2011
}

\author{
By Gönül Dönmez-Colin
}

Spring 2012 Issue of KINEMA

\section{INTERNATIONAL GOLDEN BOLL FILM FESTIVAL ADANA}

The pulse of Turkish cinema beats in Adana, the provincial southern town that is the birthplace of several notable filmmakers and writers, among whom perhaps Yllmaz Güney and Yaşar Kemal are the most prominent representatives. While political conflicts have been marring the prestigious Antalya Golden Orange Film Festival, which has served as a forum for the national film industry for several decades, Adana (17-25 September 2011) has renewed itself both at the national and international levels, attracting national production companiess with attractive cash prizes.

The fourteen Turkish films in competition included the slow paced Eylül (September) by Cemil Ağacıkoğlu about the disintegration of a relationship when faced with the pressures of sickness and temptation; the comedy-thriller Celal Tan ve Ailesinin Aşırı Acıklı Hikayesi (The Extremely Tragic Story of Celal Tan and His Family) by Onur Ünlü; a reflection on ecological damages, Yurt Home by Muzaffer Özdemir (the actor from Nuri Bilge Ceylan's The Small Town, Clouds of May and Distant, who received the Best Actor award at the Cannes Film Festival in 2003 for Distant); an exploration of the body and how individuals perceive their own, Vücut (The Body) by Mustafa Nuri (starring Hatice Arslan who had a memorable role in Ceylan's Three Monkeys); a powerful documentary, Simurg by Ruhi Karadağ about the damaged lives of people after the hunger strikes in the prisons; a docu-drama about the Jews that Turkey saved during the World War II, Türk Pasaportu (The Turkish Passport) by Burak Cem Artel (arriving amidst severed relationships between Turkey and Israel); about the Alevi massacres in 1980, Sakl Hayatlar / Hidden Lives by A. Haluk Ünal; a nostalgia piece with Hollywood flavour, Kaybedenler Kulübü (Losers' Club) by Tolga Örnek and a film on language and oppression, Gelecek Uzun Sürer (Future Lasts Forever) by Özcan Alper, about the minorities who are silenced by the dominant majority and the thirty-year-old war in Southeastern Turkey, were some of the films worth mentioning for a variety of reasons - including subject matter, acting, directing, script, although very few could be considered as all-round excellent choices. The increase in the quantity of films made in Turkey recently does not necessarily correspond to their quality and we are often left with films that start from sound premises, but slowly meander in some unknown direction.

The masters, however, are still the masters. Derviş Zaim, who explores a different genre, a different territory with each film, is one such master. The retrospective which included his complete oeuvre started with his first film, the no-budget Tabutta Rövaata (Somersault in a Coffin) and completed with his most recent, Gölgeler ve Suretler (Shadows and Faces), about a conflict which he is very familiar with, the war in Cyprus over forty years ago, which resulted in the partition of the island. The film is built around the art of shadow play, Karagöz and Hacivat, just as the previous film Nokta (Dot) was centred around calligraphy and Cenneti Beklerken (Waiting For Heaven) on miniature painting.

Ali Özgentürk who is best known for Hazal (1980) and At (The Horse, 1982); Kadir İnanır, the actor renamed 'the peoples' artist' and Nebahat Çehre who was once married to Yllmaz Güney, who played in countless films in a career that spans half a century, were honoured for lifetime achievement with a lovely volume published on each one's life and art.

The most exciting moment of the festival was the Turkish Premiere of Nuri Bilge Ceylan's Bir Zamanlar Anadolu'da (Once Upon a Time in Anatolia), an exceptional work of film art and at the same time, a clear mirror of Turkish society without being overtly political. Ceylan attended the festival and inaugurated the exhibition of his photography that traces locations of his films.

The Mediterranean Short Film Competition including fiction, documentaries, experimental film and animation, Student Films Competition and the World Cinema section with Woody Allen's Midnight in Paris comprised some of the other sections. The city of Adana paid homage to its native son, Yllmaz Güney with the screening of some of his great works such as Ăğt (Elegy, 1971) and Arkadaş (Friend,1974). 
The International Congress on Turkish cinema, organized by the 9 September University (Dokuz Eylül University) in Izmir that ran parallel to the festival with an expert publication that arrived before the closing night was itself worth the trip to Adana.

But the most special event was the inauguration of the film museum. When we think of the metropolis Istanbul lacking a bona fide museum for so long, this is no small feat. Emotions were heightened when the wife of Yllmaz Güney met his wax figure. Props from several of his films, the cameras he used, even the clothes he wore were in display along with posters and other items belonging to other films and filmmakers, including Ali Özgentürk, another native son of Adana. The museum also possesses 2000 books on cinema and will soon extend its services to a research centre.

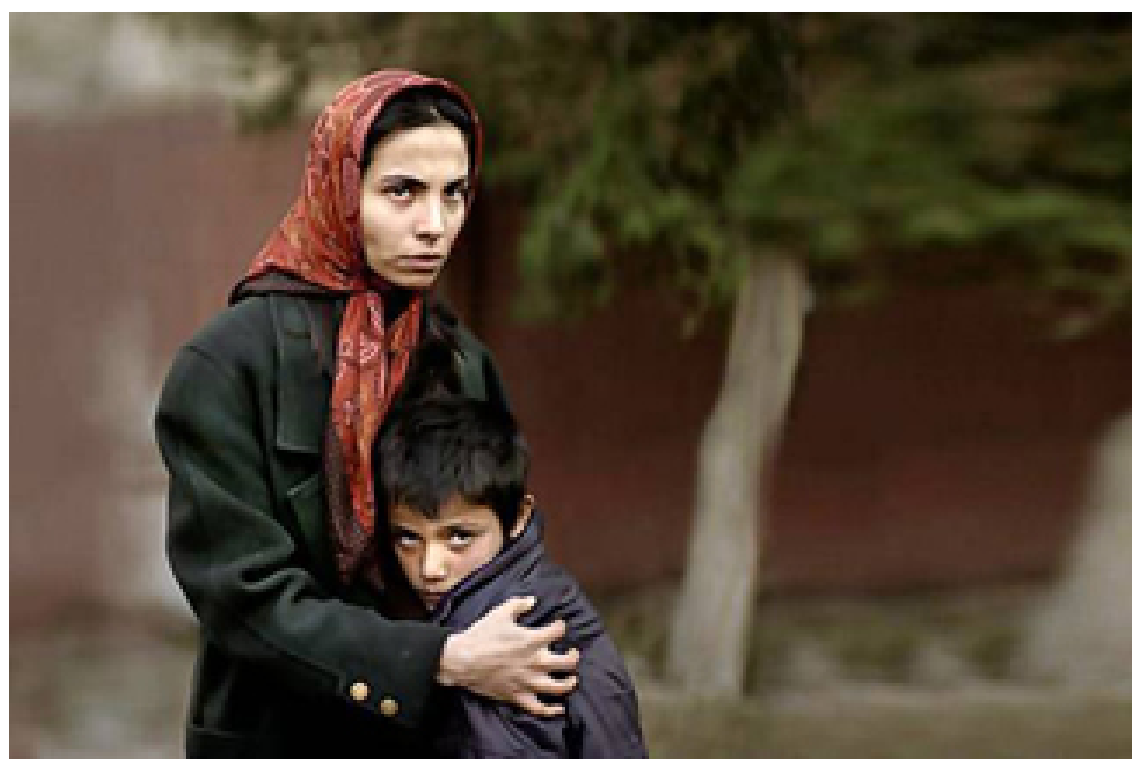

Figure 1: Scene from Once Upon a Time in Anatolia by Nuri Bilge Ceylan

\section{References}

\section{AWARDS}

Best Film

The Extremely Tragic Story of Celal Tan and His Family (Onur Ünlü)

Best Director

Cemil Ağacıkoğlu for September

Best Screenplay

Onur Ünlü for The Extremely Tragic Story of Celal Tan and His Family

Best Actor

Durukan Ordu for Future Lasts Forever

Best Actress

Hatice Aslan for The Body and Görkem Yeltan for September

Best Editing

Taner Sarf for September 
Jury Award for Best Ensemble Cast Performance The Extremely Tragic Story of Celal Tan and His Family

Best Music

Mustafa Biber for Future Lasts Forever

Best Cinematography

Feza Çaldıran for Future Lasts Forever

Special Jury Award

Love and Revolution (Aşk ve Devrim) by F. Serkan Acar

Adana Audience Award

Simurg by Ruhi Karadă̆

Yllmaz Güney Award

Future Lasts Forever by Özcan Alper

Turkish Film Critics Association (SIYAD) Best Film Award

Future Lasts Forever by Özcan Alper

\section{Author Information}

Gönül DÖNMEZ-COLIN is an independent researcher and writer whose publications include Women, Islam and Cinema, Cinemas of the Other: A personal Journey with Filmmakers from the Middle East and Central Asia, Cinema of North Africa and the Middle East (ed.); Turkish Cinema: Identity, Distance and Belonging (Reaktion Books), and Routledge Dictionary of Turkish Cinema (2014). 